\title{
PENGARUH PEMBERIAN EKSTRAK KULIT BAGIAN DALAM SEMANGKA (Citrullus lanatus) TERHADAP KEUTUHAN MEMBRAN PLASMA DAN ABNORMALITAS MORFOLOGI TIKUS JANTAN (Rattus norvegicus) SETELAH DIPAPAR SUHU PANAS
}

\author{
THE EFFECT OF WATERMELON'S INNER RIND EXTRACT (Citrullus \\ lanatus) TOWARDS THE INTEGRITY OF THE PLASMA MEMBRANE AND \\ SPERMATOZOA MORPHOLOGY ABNORMALITY OF MALE NORWAY \\ RATS (Rattus norvegicus) AFTER BEING EXPOSED TO HOT TEMPERATURE
}

\author{
Dinda Reisinta), Widya Paramita L ${ }^{2)}$, Tatik Hernawati3), Dewa Ketut Meles ${ }^{4}$, \\ Sri Pantja Madyawati ${ }^{5}$, Tri Wahyu Suprayogi' \\ ${ }^{1)}$ Student, ${ }^{2)}$ Husbandry Department, ${ }^{3,5,6)}$ Veterinary Reproduction Department, \\ ${ }^{4)}$ Veterinary Basic Medicine Departement \\ Faculty Veterinary Medicine, Airlangga University \\ email: reisinta95@gmail.com
}

\begin{abstract}
This study aims to determined the effect of watermelon's inner rind extract (Citrullus lanatus) towards the integrity of the plasma membrane and morphological abnormalities of male Norway rats's spermatozoa (Rattus norvegicus) after being exposed to hot temperature. The content of lycopene in the inner rind of watermelon serves an antioxidant counteracting free radicals. A total of 20 male Norway rats (Rattus norvegicus) were used in this study with an average age of 2 months. The study was divided into five treatments and four replications, consisting of: $\mathrm{K}(-)$ as negative control given $\mathrm{CMC} \mathrm{Na} 0.5 \%$ as much as $0.5 \mathrm{ml}, \mathrm{P} 0$ as positive control was exposed to $40^{\circ} \mathrm{C}$ for 1 hour and $\mathrm{CMC} \mathrm{Na} 0.5 \%$ of $0.5 \mathrm{ml}$. P1, P2 and P3 are exposed to $40^{\circ} \mathrm{C}$ for 1 hour and inner rind extracts of watermelon with a multilevel dose of $\mathrm{P} 1$ : 20mg/head/day, P2: 40mg/head/day, and P3: $80 \mathrm{mg} /$ head/day that each dose was dissolved in $\mathrm{CMC} \mathrm{Na} 0.5 \%$ of $0.5 \mathrm{ml}$. The results showed that giving inner rind extract of watermelon to the rats increased the integrity of the plasma membrane and decreased morphological abnormalities of male rat's spermatozoa (Rattus norvegicus). The result of increased the integrity of the plasma membrane and highest decreased morphological abnormality was shown by P3 group given a dose of $80 \mathrm{mg} / \mathrm{head} / \mathrm{day}$.
\end{abstract}

Key words: Lycopene, antioxidant, inner rind of watermelon, integrity of the plasma membrane, morphological abnormalities of spermatozoa

\section{Pendahuluan}

Peningkatan produksi daging merupakan salah satu upaya untuk mewujudkan ketahanan pangan sekaligus memajukan tingkat kecerdasan sumber daya manusia. Laju pertambahan penduduk yang terus meningkat hingga $1,43 \%$ per tahun, menuntut ketersediaan daging yang juga meningkat. Berdasarkan data Badan Pusat Statistik (2015) terlihat bahwa produksi daging Indonesia tidak dapat memenuhi kebutuhan konsumsi. Produksi dalam negeri hanya bisa memenuhi konsumsi sekitar 50-70\% saja.
Rendahnya tingkat produktivitas sapi potong disebabkan oleh banyak faktor diantaranya seperti infertilitas pada hewan jantan yang dapat disebabkan oleh kurang baiknya kualitas spermatozoa. Kualitas spermatozoa yang kurang baik dapat disebabkan oleh faktor ling-kungan (Rizal dkk., 2006). Peningkatan radikal bebas yang disebabkan oleh lingkungan merupakan salah satu etiologi infertilitas jantan. Kohen and Nyska (2002) menyatakan bahwa kualitas spermatozoa dapat menurun akibat berbagai faktor dari stres oksidatif, diantaranya adalah radiasi panas. Paparan suhu panas sebagai salah satu dari stres 
oksidatif menyebabkan infertilitas melalui efek negatif-nya ke spermatozoa seperti peningkatan kerusakan membran plasma dan abnormalitas morfologi spermatozoa (Batubara, 2013).

Spermatozoa yang memiliki abnormallitas morfologi dapat menyebabkan gangguan dan hambatan pada saat fertilisasi sehingga dapat menyebabkan rendahnya angka kebuntingan (Afiati dkk., 2015). Selain itu kerusakan membran plasma spermatozoa mengakibatkan terganggunya transfer aktif zat yang menjadi sumber energi bagi spermatozoa seperti glukosa, asam amino, dan asam lemak, sehingga daya hidup spermatozoa akan menurun (Correa and zavos, 1994).

Tubuh makhluk hidup secara alami memiliki sistem pertahanan terhadap radikal bebas, yaitu antioksidan endogen. Pada keadaan patologik akibat terbentuknya radikal bebas dalam jumlah berlebihan, antioksidan endogen dapat menurun aktivitasnya. Oleh karena itu, jika terjadi peningkatan radikal bebas dalam tubuh, dibutuhkan antioksidan eksogen (berasal dari bahan pangan yang dikonsumsi) dalam jumlah yang lebih banyak untuk mengeliminir dan menetralisisr efek radikal bebas (Astuti, 2008). Antioksidan eksogen dapat berasal dari senyawa karotenoid, salah satu golongan karotenoid adalah likopen yang terdapat dalam semangka. Semangka (Citrullus lanatus) merupakan salah satu tanaman yang banyak diminati oleh masyarakat umum. Konsumsi buah semangka menghasilkan limbah berupa kulit semangka yang belum dimanfaatkan secara optimal. Oleh karena itu, untuk meningkatkan nilai tambahnya, limbah kulit semangka dapat dimanfaatkan sebagai sumber antioksidan yaitu likopen.

Pada penelitian ini peneliti ingin menguji seberapa besar pengaruh pemberian ekstrak kulit bagian dalam semangka (Citrullus lanatus) yang mengandung likopen sebagai antioksidan terhadap keutuhan membran plasma dan abnormalitas morfologi spermatozoa yang dilakukan pada hewan coba tikus jantan (Ratus norvegicus) setelah dipapar dengan suhu panas.

\section{Rumusan Masalah}

1. Apakah pemberian ekstrak kulit bagian dalam semangka (Citrullus lanatus) dapat mempengaruhi keutuhan membran plasma spermatozoa tikus jantan (Rattus norvegicus) setelah dipapar dengan suhu panas?

2. Apakah pemberian ekstrak kulit bagian dalam semangka (Citrullus lanatus) dapat mempengaruhi abnormalitas morfologi spermatozoa tikus jantan (Rattus norvegicus) setelah dipapar dengan suhu panas?

\section{Tujuan Penelitian}

1. Untuk mengetahui efek ekstrak kulit ba-gian dalam dari buah semangka (Citrullus lanatus) terhadap keutuhan membran plasma spermatozoa tikus jantan (Rattus norvegicus) setelah dipapar dengan suhu panas.

2. Untuk mengetahui efek ekstrak kulit bagian dalam dari buah semangka (Citrullus lanatus) terhadap abnormallitas morfologi spermatozoa tikus jantan (Rattus norvegicus) setelah dipapar dengan suhu panas.

\section{Manfaat Penelitian}

Hasil dari penelitian ini diharapkan dapat memberikan informasi ilmiah tentang pengaruh dari pemberian ekstrak kulit bagian dalam buah semangka (Citrullus lanatus) terhadap keutuhan membran plasma dan abnormalitas morfologi spermatozoa tikus jantan (Rattus norvegicus) setelah dipapar dengan suhu panas.

\section{Tempat dan Waktu Penelitian}

Penelitian ini dilaksanakan di Laboratorium Farmakologi Departemen Ilmu Kedokte-ran Dasar Veteriner, Kandang Hewan Coba, dan Laboratorium Patologi Departemen Patologi Veteriner Fakultas Kedokteran Hewan Universitas Airlangga Surabaya. Penelitian dilaksanakan pada bulan April-Juni 2017.

\section{Bahan dan Alat Penelitian}

Penelitian ini menggunakan hewan coba tikus jantan (Rattus norvegicus) umur 2 bulan berat \pm 200 gram dengan jumlah 20 ekor. Bahan yang digunakan adalah kulit bagian dalam semangka (Citrullus lanatus), $\mathrm{NaCl} 0,9 \%$, etanol $96 \%$, fruktosa, sodium citrate, aquades, methanol, giemsa 3\%, dan $\mathrm{CMC} \mathrm{Na} 0,5 \%$. Alat untuk penelitian ini adalah timbangan, mesin penggiling te- 
pung, rotary evaporator, tempat pakan dan minum, kandang hewan coba, inkubator buatan dari kardus yang berisi lampu pijar 60 watt 2 buah, thermometer ruangan, sonde lambung tuberculin $1 \mathrm{ml}$, papan penyangga dan seperangkat alat bedah, gelas objek, cover glass, pipet, mikroskop, hand tally.

\section{Metode Penelitian}

Tikus jantan (Rattus norvegicus) umur 2-3 bulan dengan berat \pm 200 gram diadaptasikan dengan lingkungan kandang selama tujuh hari. Hewan coba terdiri dari lima perlakuan, dan masing-masing perlakuan teridiri dari empat ulangan. Lima perlakuan tersebut antara lain sebagai berikut: $\mathrm{K}(-)$ sebagai kontrol negatif tanpa paparan panas dan ekstrak kulit bagian dalam semangka, P0 diberikan paparan panas $40^{\circ} \mathrm{C}$ selama 1 jam tanpa diberi ekstrak kulit bagian dalam semangka, P1 diberikan ekstrak kulit bagian dalam semangka 20mg/ekor/hari dalam CMC $\mathrm{Na} 0,5 \%$ sebanyak $0,5 \mathrm{ml}$ secara per oral lalu dipapar suhu panas $40^{\circ} \mathrm{C}$ selama 1 jam, P2 diberikan ekstrak kulit bagian dalam semangka 40mg/ekor/hari dalam CMC Na 0,5\% sebanyak $0,5 \mathrm{ml}$ secara per oral lalu dipapar suhu panas $40^{\circ} \mathrm{C}$ selama 1 jam, P3 diberikan ekstrak kulit bagian dalam semangka 80mg/ekor/hari dalam CMC Na 0,5\% sebanyak $0,5 \mathrm{ml}$ secara per oral lalu dipapar suhu panas $40^{\circ} \mathrm{C}$ selama $1 \mathrm{jam}$.

Setelah 52 hari perlakuan, semua tikus dikorbankan. Kemudian spermatozoa diambil pada bagian proksimal kauda epididimis dengan cara streaping dan ditampung dalam cawan petri yang telah diisi $1 \mathrm{ml}$ larutan $\mathrm{NaCl}$ fisiologis. Suspensi spermatozoa siap diguna-kan untuk pemeriksaan keutuhan membran plasma dan abnormalitas morfologi spermatozoa.

\section{Hasil Dan Pembahasan \\ Keutuhan Membran Plasma Sperma- tozoa}

Hasil persentase rata-rata keutuhan membran plasma spermatozoa tikus jantan (Rattus norvegicus) yang diberi paparan panas dan ekstrak kulit bagian dalam semangka dapat dilihat dalam tabel 1 . Berdasarkan hasil tersebut menunjukkan penurunan yang signifikan antara $\mathrm{K}(-)$ sebagai kontrol negatif dan $\mathrm{P} 0$ yang diberi paparan panas $40^{\circ} \mathrm{C}$ selama 1 jam. Hal ini karena adanya paparan panas sebagai radikal bebas yang menyebabkan membran plasma spermatozoa rusak. Keadaan ini nampaknya sesuai dengan pendapat Umar dkk. (2015) yang menyatakan bahwa suhu panas $40^{\circ} \mathrm{C}$ memicu terjadinya stress oksidatif yang dapat menurunkan kualitas spermatozoa.

Kerusakan membran plasma menjadi penyebab modulator pembentukan ROS oleh spermatozoa. ROS merupakan oksidan kuat karena reaktifitas tinggi sehingga dapat meru-sak komponen sel yang penting untuk mempertahankan keutuhan membran plasma spermatozoa (Susilowati, 2008; Utomo, 2011). Membran plasma spermatozoa yang rusak terlihat dari bentuk ekor yang tidak menggulung setelah ditambah larutan HOS. Kerusakan membran spermatozoa dapat disebabkan oleh stress oksidatif yang ditimbulkan oleh radikal bebas (Sikka, 2004).

Pada perlakuan P1 dengan dosis ekstrak $20 \mathrm{mg} / \mathrm{ekor} / \mathrm{hari}$ dan $\mathrm{P} 2$ dengan dosis ekstrak $40 \mathrm{mg} / \mathrm{ekor} / \mathrm{hari}$ sudah dapat meningkatkan keutuhan membran plasma

Tabel 1. Rata-rata dan Standar Deviasi Keutuhan Membran Plasma Spermatozoa Dari Berbagai Perlakuan

\begin{tabular}{cc}
\hline Perlakuan & $\begin{array}{c}\text { Keutuhan membran plasma Spermatozoa } \\
(\mathbf{x} \pm \mathbf{S D})\end{array}$ \\
\hline K(-) & $11,3^{\mathrm{b}} \pm 2,0$ \\
P0 & $3,7^{\mathrm{a}} \pm 2,0$ \\
P1 & $9,6^{\mathrm{b}} \pm 2,0$ \\
P2 & $13,9^{\mathrm{bc}} \pm 2,0$ \\
P3 & $18,5^{\mathrm{c}} \pm 3,0$ \\
\hline
\end{tabular}

Superskrip $\left({ }^{\mathrm{a}, \mathrm{b}, \mathrm{c}}\right)$ pada kolom yang sama menunjukkan perbedaan yang nyata (signifikan) antara perlakuan $(\mathrm{p}<0,05)$. 
spermatozoa serta berbeda nyata terhadap perlakuan P0 sebagai kontrol positif. Tetapi perlakuan P1 memiliki hasil rataan lebih rendah serta tidak berbeda nyata terhadap $\mathrm{K}(-)$ sebagai kontrol negatif. Kolawole et al. (2014) menyatakan bahwa dengan dosis efektif sebesar 40mg/ekor/hari dapat meningkatkan kualitas spermatozoa tikus dibandingkan dengan kontrol negatif tanpa diberi paparan suhu panas. Berdasarkan hasil penelitian ini perlakuan P1 dapat meningkatkan keutuhan membran plasma spermatozoa meski belum dapat mengembalikan pada keadaan normal tanpa paparan. Hal tersebut diakibatkan karena P1 diberi paparan panas $40^{\circ} \mathrm{C}$ selama 1 jam dan diberi ekstrak kulit bagian dalam semangka dibawah dosis efektif yaitu 20mg/ekor/hari.

Perlakuan yang menunjukkan hasil paling baik untuk meningkatkan keutuhan membran plasma spermatozoa adalah perlakuan P3 yang diberikan ekstrak kulit bagian dalam semangka dengan dosis dua kali dosis efektif yaitu $80 \mathrm{mg} / \mathrm{ekor} / \mathrm{hari}$. Keadaan ini nampaknya sesuai dengan pendapat Durairajanayagam et al. (2014) yang menyatakan bahwa kandungan likopen dalam kulit bagian dalam semangka berfungsi sebagai antioksidan yang mampu melawan radikal bebas yang masuk ke dalam tubuh.
Likopen terbukti membawa aktivitas anti-oksidan dan dapat menangkal adanya radikal bebas terhadap infertilitas (Tamilselvan et al., 2013). Spermatozoa dibungkus oleh membran yang berfungsi sebagai pelindung spermatozoa terhadap perubahan lingkungan. Bila spermatozoa terpapar pada medium hipoosmotik antara larutan di dalam dan di luar spermatozoa, maka spermatozoa akan bengkak atau melengkung. Peritistiwa pada spermatozoa ini dapat terjadi karena membran selnya bersifat semi permiable dan berfungsi normal (Affandhy dkk., 2008).

\begin{abstract}
Abnormalitas morfologi spermatozoa
Hasil persentase rata-rata abnormalitas morfologi spermatozoa tikus jantan (Rattus norvegicus) yang diberi ekstrak kulit bagian dalam semangka dapat dilihat dalam tabel 2. Berdasarkan hasil tersebut menunjukkan peningkatan abnormalitas morfologi yang signifikan antara $\mathrm{K}(-)$ sebagai kontrol negatif dan P0 yang diberi paparan panas $40^{\circ} \mathrm{C}$ selama 1 jam. Hal ini karena adanya paparan panas sebagai radikal bebas yang menyebabkan abnormalitas morfologi spermatozoa. Keadaan ini nampaknya sesuai dengan pendapat Umar dkk. (2015) yang menyatakan bahwa meningkatnya abnormalitas morfologi disebabkan paparan suhu panas $40^{\circ} \mathrm{C}$ selama 1 jam yang memicu terjadinya stress oksidatif.
\end{abstract}

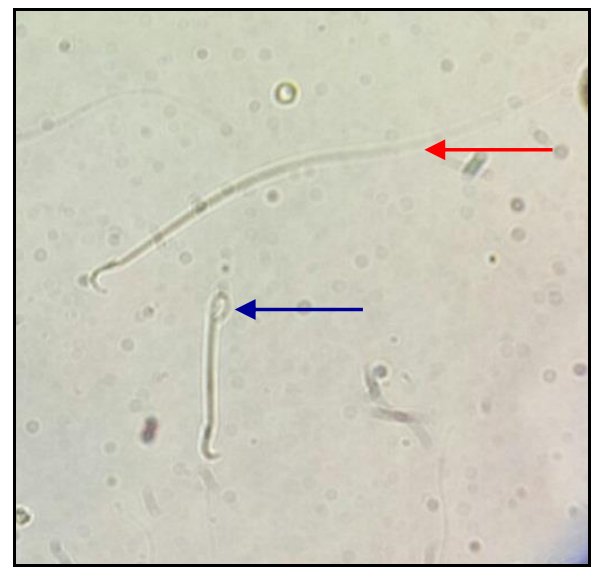

Gambar 1. Hasil pemeriksaan keutuhan membran plasma spermatozoa menggunakan mikroskop Keterangan: perbesaran $400 \mathrm{x}$.

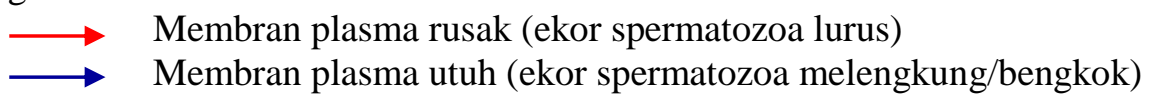


Tabel 2. Rata-rata dan Standar Deviasi Abnormalitas Spermatozoa dari Berbagai Perlakuan

\begin{tabular}{cc} 
Perlakuan & $\begin{array}{c}\text { Abnormalitas Morfologi Spermatozoa } \\
(\mathbf{x} \pm \mathbf{S D})\end{array}$ \\
\hline K(-) & $23,0^{\mathrm{a}} \pm 4,0$ \\
P0 & $41,1^{\mathrm{b}^{\mathrm{a}} \pm 8,0}$ \\
P1 & $28,8^{\mathrm{ab}} \pm 9,0$ \\
P2 & $21,1^{\mathrm{a}} \pm 5,0$ \\
P3 & $15,0^{\mathrm{a}} \pm 7,0$ \\
\hline
\end{tabular}

Superskrip (a,b) pada kolom yang sama menunjukkan perbedaan yang nyata (signifikan) antara perlakuan $(\mathrm{p}<0,05)$.

Paparan suhu panas $40^{\circ} \mathrm{C}$ menyebabkan terjadinya kerusakan enzim karena pada suhu yang lebih tinggi terjadi denaturasi (hilangnya struktur sekunder dan tersier). Terhambatnya kerja enzim Adenilat Siklase menyebabkan konversi ATP menjadi cAMP terganggu sehingga sekresi testosterone juga terganggu. Akibatnya spermatogenesis juga terganggu dan mengakibatkan morfologi yang normal akan mengalami gangguan (Ermiza, 2012).

Pada perlakuan P1 dengan dosis ekstrak $20 \mathrm{mg} / \mathrm{ekor} / \mathrm{hari}$ bila dibandingkan dengan P0 sebagai kontrol positif sudah dapat menurunkan abnormalitas morfologi spermatozoa. Tetapi bila dibandingkan dengan $\mathrm{K}(-)$ sebagai kontrol negatif, belum dapat menurunkan abnormalitas morfologi spermatozoa. Berdasarkan hasil penelitian ini perlakuan P1 dapat menurunkan abnormalitas morfologi spermatozoa meski belum dapat mengembalikan pada keadaan normal (perlakuan K(-)).

Berdasarkan hasil penelitian ini perlakuan P2 dengan dosis ekstrak 40 $\mathrm{mg} / \mathrm{ekor} /$ hari dan P3 dengan dosis ekstrak
$80 \mathrm{mg} / \mathrm{ekor} /$ hari sudah dapat menurunkan abnormalitas morfologi spermatozoa dan dapat mengembalikan ke keadaan normal. Abnormalitas morfologi spermatozoa terendah dalam penelitian ini terdapat pada perlakuan P3. Penurunan persentase abnormalitas morfologi spermatozoa disebab-kan karena peran likopen sebagai antioksidan yang mampu mereduksi stres oksidatif akibat paparan suhu panas dan menjaga kualitas spermatozoa dengan cara mengikat radikal bebas dan mencegah terjadinya perluasan reaksi cincin radikal, sehingga dapat mencegah terjadinya stress oksidatif pada lemak, protein, dan DNA dari sel spermatozoa (Durairajanayagam et al., 2014).

\section{Kesimpulan}

1. Pemberian ekstrak kulit bagian dalam dari buah semangka (Citrullus lanatus) dapat mempengaruhi keutuhan mem-bran plasma spermatozoa tikus jantan (Rattus norvegicus) setelah diberi paparan panas $40^{\circ} \mathrm{C}$ selama 1 jam / hari dalam waktu 52 hari.

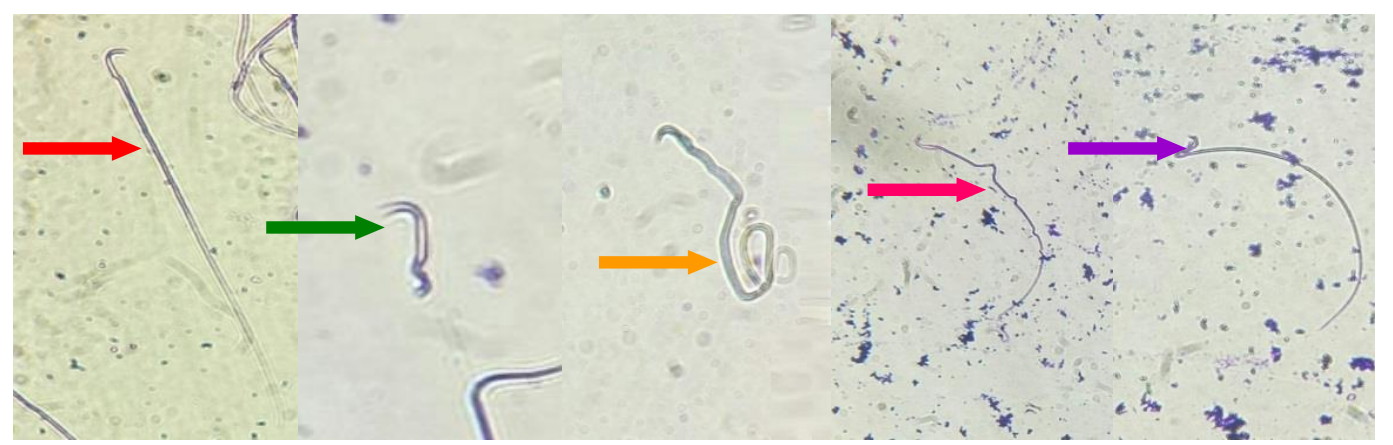

Gambar 2. Hasil pemeriksaan abnormalitas morfologi spermatozoa menggunakan perbesaran $400 \mathrm{x}$.

Keterangan:

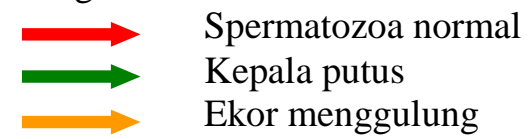

Bagian tengah melengkung

Kepala terlipat 
2. Pemberian ekstrak kulit bagian dalam dari buah semangka (Citrullus lanatus) dapat mempengaruhi abnormalitas morfologi spermatozoa tikus jantan (Rattus norvegicus) setelah diberi paparan panas $40^{\circ} \mathrm{C}$ selama $1 \mathrm{jam} /$ hari dalam waktu 52 hari.

\section{Daftar Pustaka}

Affandy, L., C. Pratiwi dan D. Ratnawati. 2009. Kualitas Semen Pejantan Sa-pi Peranakan Ongole (PO) dengan Perlakuan Pemberian Suplemen Tradisional. Seminar Nasional Teknologi Peternakan dan Veteriner.

Afiati, F., Yulnawati, Riyadi dan M. Arifiantini, R.I. 2015. Abnormalitas Spermatozoa Domba dengan Frekuensi Penampungan Berbeda. Pros Sem Nas Masy Biodiv Indon. 1: 930934.

Astuti, S. 2008. Isovlavon Kedelai dan Potensinya Sebagai Penangkap Radi-kal Bebas. Jurnal Teknologi Indus-tri dan hasil pertanian. 13(2): 128-131.

Badan Pusat Statistik. 2015. Agribisnis Usaha Rumah Tangga Budidaya Sapi dan Target Swasembada. Jakarta. Badan Pusat Statistik. 18.

Batubara, I.V.D., B. Wantouw dan L. Tendean. 2013. Pengaruh Paparan Asap Rokok Kretek Terhadap Kualitas Spermatozoa Mencit Jantan (Mus musculus). Jurnal e-Biomedik (eBM). 1(1): 331-333.

Correa, J.R. and P.M. Zavos. 1994. The Hypoosmotic Swelling Test. Its employment as an assay to evaluate. The function integrity of the frozenthawed bovine sperm membrane. Theriogenology 42: 351-360.

Durairajanayagam, D., A. Aagarwal, C. Ong and P. Prashat. 2014. Lycopene and Male Infertility. Asian Journal of Andrology. 16: 420-425.

Ermiza. 2012. Pengaruh Paparan Suhu Terhapap Kualitas Spermatozoa Mencit Jantan (Mus musculus) Strain Jepang. Sainstis. 1: 20-27.

Kohen, R. and A. Nyska. 2002. Oxidation of Biologycal System: Stress oksidative Phenomena, Antioxidants, Redox Reactions, and Me-thods for Their Quantification. School of Environmental Health Sciences (NIEHS).
Toxicology Pathology. Nort California. 30(6): 620-650.

Kolawole, T. A., D. V. Dapper and S. O. Ojeka. 2014. Ameliorative Effects of the Methanolic Extract of the Rind of Citrullus lanatus on Lead Acetate Induce Toxicity on Semen Parameters and Reproductive Hormones of Male Albino Wistar Rats. European Journal of Medicinal Plants. 11251137.

Rizal, M., Herdis, A., Budiono, A.S., dan Yunalwati. 2006. Peranan Beberapa Jenis Gula dalam Meningkatkan Kualitas Semen Beku Domba Garut. J. Ilmu Ternak dan Vet. Puslitbang Peternakan. Balitbang Pertanian Departemen Pertanian. 11(2): 123130.

Sikka, S.C. 2004. Role of Oxidative Stress and Antioxidants in Andrology and Assisted Reproductive Technology. J. Androl. 25(1): 5-18.

Susilowati, S. 2008. Komplek Insulin Like Growth Faktor-I Mempengaruhi Presentase Membran Plasma Utuh dan Kadar Malondialdehid Spermatozoa. Jurnal Veteriner. 9(4): 168-175.

Tamilselvan, P., K. Bharathiraja, S. Vijayaprakash and M.P. Balasubramanian. 2013. Protective Role Of Lycopene On Bisphenol A Induced Changes In Sperm Characteristics, Testicular Damage And Oxidative Stress In Rats. Journal of Pharmacy and Biological Siences. 4: $131-143$.

Umar, S.H., Q. Edwin dan L. Tendean. 2015. Pengaruh Pemberian Ekstrak Kulit Buah Manggis (Garcinia mangostana L.) Terhadap Kualitas Spermatozoa Wistar Jantan (Rattus norvegicus) yang Diberi Paparan Suhu Panas. Jurnal e-Biomedik. 3(2): 671-672.

Utomo, B. 2011. Suplementasi Akrosin Pada Semen Kambing Peranakan Etawa (PE) Pasca Thawing Terhadap Peningkatan Kualitas dan Potensi Spermatozoa. Progam Pascasarjana. Universitas Airlangga. Suarabaya. 